\title{
PELATIHAN PENULISAN KARYA TULIS ILMIAH KEPADA GURU SMP SE-KOTA PONTIANAK
}

\author{
Al Ashadi Alimin', Mesterianti Hartati ${ }^{2}$, Mai Yuliastri Simarmata ${ }^{3}$ \\ ${ }^{1,2,3}$ Program Studi Pendidikan Bahasa dan Sastra Indonesia, Fakultas Pendidikan Bahasa dan Seni, \\ IKIP PGRI Pontianak, Jalan Ampera No.88 Pontianak \\ e-mail: alashadialimin@ikippgriptk.ac.id
}

\begin{abstract}
Abstrak
Tujuan pelatihan dalam kegiatan PKM ini adalah; terlaksananya pelatihan penelitian tindakan kelas, menambah pemahaman guru terhadap karya tulis ilmiah berupa penelitian tindakan kelas, dan diperoleh rencana judul yang nantinya dapat dikembangkan oleh guru-guru menjadi suatu bentuk penelitian tindakan kelas. Kegiatan pengabdian kepada masyarakat (PKM) dilakukan oleh tim dosen Program Studi Pendidikan Bahasa dan Sastra Indonesia IKIP PGRI Pontianak yang ditujukan kepada guru SMP Se-Kota Pontianak yang tergabung dalam MGMP bahasa Indonesia tingkat SMP Kota Pontianak yang berjumlah 40 orang peserta. Kegiatan dilaksanakan dalam dua bentuk kegiatan yaitu (1) metode ceramah dan tanya jawab digunakan untuk menjelaskan teori mengenai karya tulis ilmiah serta penelitian tindakan kelas, (2) metode simulasi dan metode praktik digunakan untuk tahap kegiatan pelatihan yang menitikberatkan pada kemampuan melaksanakan penelitian tindakan kelas. Keberhasilan kegiatan diukur menggunakan dua cara yaitu (1) angket respon peserta terhadap materi yang disajikan, (2) Proposal PTK yang ditulis oleh peserta pelatihan. Selama pelasanaan kegiatan materi yang disampaikan dapat diterima dengan baik oleh peserta, akan tetapi karena keterbatasan waktu peserta pelatihan belum optimal dalam praktik tahapan pelaksanaan PTK.
\end{abstract}

Kata kunci: penelitian tindakan, karya tulis ilmiah

\begin{abstract}
The training objectives in this PKM activity are; implementation of classroom action research training, increase teacher understanding of scientific papers in the form of classroom action research, and obtained title plans that can later be developed by teachers into a form of classroom action research. Community service activities (PKM) are carried out by a team of lecturers of the Indonesian Language and Literature Education Study Program IKIP PGRI Pontianak aimed at Pontianak City Middle School teachers who are members of the MGMP bahasa Indonesian tingkat SMP totaling 40 participants. Activities are carried out in two forms of activities; (1) lecture and question and answer methods are used to explain theories about scientific writing and classroom action research (CAR), (2) simulation methods and practice methods are used for the stage of training activities that focus on the ability to carry out CAR. The success of the activity was measured using two methods, namely: (1) questionnaire responses of participants to the material presented, (2) CAR proposal written by the trainees. During the implementation of the activity the material delivered was well received by the participants, but due to the limited time the trainees were not optimal in the practice stages of the CAR implementation.
\end{abstract}

Keywords: classroom action research, writing scientific papers 


\section{PENDAHULUAN}

Budaya literasi dibutuhkan sebagai guru yang profesional, kebutuhan dasar dan budaya yang harus ditumbuh kembangkan. Literasi erat kaitannya dengan baca dan tulis. Guru dikatakan memiliki budaya litersi yang baik ditandai dengan gemar membaca dan menulis. Program literasi yang ada di sekolah tentunya akan berhasil ketika guru bisa menjadi pelopor dalam menumbuhkan budaya sadar literasi. Sebagaimana yang diutarakan Wiedarti, Laksono, dan Retnaningsih (2018). Gerakan literasi sekolah (GLS) diharapkan mampu menggerakkan warga sekolah, pemangku kepentingan, dan masyarakat untuk bersama-sama memiliki, melaksanakan, dan menjadikan gerakan ini sebagai bagian penting dalam kehidupan yang warganya literat sepanjang hayat.

Guru hendaknya memiliki minat yang tingggi terhadap membaca dan menulis. Guru yang produktif dalam menghasilkan karya tulis tentunya memiliki kebangggaan tersendiri. Untuk itu dalam program pengembangan keprofesian berkelanjutan (PKB) sebagai bagian dari penilaian kinerja guru (PKG) mewajibkan guru untuk melaksanakan pengembangan diri, membuat publikasi ilmiah, dan atau membuat karya inovatif. Hal ini dapat dilakukan secara mendiri, melalui sekolah, musyawarah guru mata pelajaran atau lemabaga diklat.

Karya tulis ilmiah bagi guru, selain sebagai pengembang budaya literasi, juga dibutuhkan oleh para guru guna kenaikan pangkat dan golongan. Sebagaimana yang diutarakan Suprayitno (2019); Kemendikbud, (2016a); Kemendikbud, (2016b) Adanya kebijakan pemerintah mengenai kenaikan pangkat, khususnya dari III C ke III D dan seterusnya satu diantaranya harus memiliki karya tulis ilmiah yang diseminarkan. Permasalahan yang sering menjadi kendala di lapangan, banyak guru yang mengalami kesulitan dalam penulisan karya tulis ilmiah ini. Apalagi bagi guru-guru senior yang telah lama menyelesaikan pendidikan terakhirnya, sehingga lupa mengenai tata cara penulisan karya ilmiah. Guru-guru lama juga banyak yang kurang menguasai pengetikan, dan tidak sedikit pula yang mengalami kesulitan dalam menemukan topik yang tepat untuk karya ilmiahnya. 
Dalam membuat publikasi ilmiah, seorang guru diharapkan mampu membuat penelitian, dalam bentuk penelitian tindakan kelas, penelitian eksperimen, atau penelitian diskriptif. Sangat dianjurkan seorang guru melakukan penelitian tindakan kelas (PTK) dengan beberapa alasan yang mengharuskan guru melakukan penelitian tindakan kelas tersebut (Utomo, 2016; Hanifah, 2014; Afandi, 2014; Aqib, 2009) ada beberapa alasan lainnya mengapa guru harus melakukan penelitian tindakan kelas. PTK adalah kebutuhan bagi guru untuk meningkatkan profesionalisme-nya antara lain: 1. membuat guru menjadi peka dan tanggap terhadap dinamika pembelajaran di kelas, 2. Meningkatkan professionalism sesame guru, 3. dapat memperbaiki proses dalam pembelajaran, 4. tidak mengganggu tugas pokok seorang guru, 5. kegiatan penelitian yang terintegrasi dengan pelaksanaan proses pembelajaran, 6. guru menjadi kreatif dan dituntut untuk melakukan upaya inovasi sebagai implementasi dan adaptasi terhadap berbagai teori dan teknik pembelajaran serta bahan ajar yang digunakan

Berdasarkan paparaan di atas, Tim Dosen Program Studi Pendidikan Bahasa dan Sastra Indonesia IKIP PGRI Pontianak, berupaya melakukan pengabdian pada masyarakat khususnya guru bahasa Indonesia yang bergabung di MGMP bahasa Indonesia Tingkat SMP Se-Kota Pontianak dalam rangka mempersiapkan dan memotivasi guru agar dapat menciptakan karya tulis ilmiah, serta menumbuhkan kesadaran budaya literasi di sekolah serta membantu guru dalam melakukan penelitian tindakan kelas

Terpilihnya musyawarah guru mata pelajaran (MGMP) sebagai sasaran kegiatan dengan beberapa pertimbangan. Musyawarah guru mata pelajaran merupakan wadah yang profesi yang strategis dalam pemberdayaan guru dalam meningkatkan kualifikasi profesional sesuai standar pendidik mengacu pada Standar Nasional Pendidikan (SNP). Sebagaimana dinyatakan (Hermawati, 2017; Ma'rifataini, 2014) kegiatan MGMP diharapkan dapat berfungsi dalam meningkatkan mutu guru dalam peningkatan mutu pembelajaran di sekolah. MGMP sebagai wadah profesi yang strategis dalam memberdayakan guru, agar guru benar-benar menjadi guru yang profesional, dan menguasai kompetensi sesuai standar pendidik yang disyaratkan dalam SNP. Untuk itu tim dosen 
Program Studi Pendidikan Bahasa dan Sastra Indonesia IKIP PGRI Pontianak memilih MGMP bahasa Indonesia Tingkat SMP Se-Kota Pontianak sebagai sasaran kegiatan PKM.

Pengabdian Kepada Masyarakat diadakan di SMPN 2 Pontianak bekerja sama dengan MGMP Bahasa Indonesia tingkat SMP. Sasaran Kegiatan ini adalah guru bidang studi bahasa Indonesia Se-Kota Pontianak yang tergabung dalam MGMP bahasa Indonesia tingkat SMP Se-Kota Pontianak. Sebagai Sekolah Model SMPN 2 Pontianak telah banyak mengukir prestasi dan memiliki SDM yang profesional sehingga diharapkan kegiatan pelatihan yang berkerjasama dengan MGMP yang dipusatkan di SMPN 2 Pontianak dapat merangkul lebih banyak guru di sekolah lainnya agar bersama-sama mewujudkan budaya sadar literasi di kalangan guru.

Dari kegiatan pelatihan ini, terdapat dua target yang dijadikan sasaran ketercapaian kegiatan. Dua aspek yang menjadi target yang diharapkan dari kegiatan pelatihan ini dintaranya; Pertama, menambah pemahaman guru terhadap karya tulis ilmiah berupa penelitian tindakan kelas. Dari kegiatan pelatihan ini, diketahui rata-rata guru yang masih belum termotivasi dalam menulis ilmiah serta kurang memahami mengenai penelitian tindakan kelas. Kedua, dari kegiatan ini target selanjutnya adalah diperoleh rencana judul yang nantinya dapat dikembangkan oleh guru-guru menjadi suatu bentuk penelitian tindakan kelas.

\section{METODE}

Pelatihan penulisan karya ilmiah berupa Penelitian Tindakan Kelas (PTK) dilakukan dengan pemberian materi ataupun teori yang berkaitan dengan PTK. selanjutnya perserta dibimbing untuk menerapkan hasil pelatihan dalam rangka meningkatkan kemampuan guru menulis karya ilmiah berupa PTK. Lokasi pelaksanaan dalam program pengabdian kepada masyarakat diadakan di SMPN 2 Pontianak. Adapun yang menjadi mitra dalam kegiatan ini adalah MGMP Bahasa Indonesia Tingkat SMP Kota Pontianak. Adapun peserta dalam kegiatan ini dihadiri oleh 40 peserta yang merupakan guru mata pelajaran bahasa Indonesia. Lokasi SMPN 2 Pontianak yang terletak tepat di pusat Kota Pontianak merupakan 
letak strategis terutama akses bagi guru dalam melakukan pertemuan-pertemuan rutin MGMP mata pelajaran Bahasa Indonesia di Kota Pontianak.

Beberapa metode yang digunakan diantaranya metode ceramah dan tanya jawab digunakan pada saat pemaparan materi berupa; konsep penelitian tindakan kelas, model-model pembelajaran inovatif dan pemanfaatan internet sebagai sumber referensi. Metode simulasi dan metode praktik digunakan untuk praktik penulisan penelitian tindakan kelas, tahap kegiatan pelatihan ini menitikberatkan pada kemampuan guru sebagai peserta pelatihan dalam merancang dan melaksanakan penelitian tindakan kelas.

Pada kegiatan pengabdian kepada masyarakat ini, melalui tahapan berikut: Pertama, tahap pendahuluan meliputi survey, penentuan lokasi dan persiapan materi. Kedua, tahap pelaksanaan pelatihan meliputi menjelaskan tentang karya tulis ilmiah. Ketiga, sesi pelatihan yang menitikberatkan pada kemampuan melaksanakan penelitian tindakan kelas. Keempat, tahap evaluasi.

Pada tahap evaluasi program, untuk mengetahui keberhasilan program pelatihan merujuk pada; 1. Untuk mengetahui tingkat pemahaman peserta digunakan angket guna mengetahui respon guru terhadap materi pelatihan, 2 . Untuk melihat sampai sejauh mana kemampuan peserta dalam melaksankan penelitian dihitung berdasarkan jumlah persentase judul yang diajukan.

\section{HASIL DAN PEMBAHASAN}

Tahap persiapan pelaksaan pengabdian kepada masyarakat dimulai dengan analisis kebutuhan yang ada di lapangan. Fakultas Pendidikan Bahasa dan Seni telah menjalin kerjasama dengan MGMP Bahasa Indonesia Tingkat SMP Kota Pontianak, hasil pembicaraan bersama Ketua MGMP Ibu Suryani, S.Pd. perlu diadakan kegiatan melibatkan dosen terutama untuk penelitian tindakan kelas. Analisis kebutuhan yang ada di lapangan menunjukkan peran MGMP sebagai wadah profesi yang strategis dalam memberdayakan guru, peran MGMP dalam meningkatkan mutu guru menjadi guru yang profesional perlu kiranya kegiatan pelatihan PTK sebagai bentuk program pengembangan keprofesian kerkelanjutan (PKB) sebagaimana diutarakan Langgau dan Mataputun (2016) pelatihan yang 
diadakan di MGMP merupakan salah satu bentuk diklat fungsional yang dilakukan secara terus menerus sebagai upaya untuk meningkatkan kompetensi guru.

Menentukan target luaran juga dilaksanakan pada tahap persiapan pelaksanaan. Beberapa aspek yang menjadi target luaran dalam kegiatan ini diantaranya; (1) terlaksananya program pengabdian kepada masyarakat dalam bentuk pelatihan penelitian tindakan kelas, dan (2) meningkatnya pemahaman guru terhadap karya tulis ilmiah berupa penelitian tindakan kelas. Langkah berikutnya pada tahap persiapan adalah menyusun proposal pengabdian kepada masyarakat untuk mengajukan pendanaan. Dalam hal ini pengabdian kepada masyarakat yang akan dilaksanakan di SMP Negeri 2 Pontianak menggunakan sumber anggaran dari IKIP-PGRI Pontianak.

Pada tahap pelaksanaan program pelatihan penulisan karya tulis ilmiah kepada guru SMP Se-Kota Pontianak dilaksanakan pada tanggal 13-14 September 2019. Kegiatan ini meliputi beberapa agenda kegiatan sebagai berikut: (1) persiapan pelaksanaan kegiatan dimulai dengan penyelesaian administrasi bagi peserta pelatihan meliputi koordinasi dengan MGMP terkait jumlah registrasi peserta pelatihan, starter kit yang diperlukan selama pelatihan, hingga menentukan waktu dan tempat pelaksanaan pelatihan, (2) sebelum diberikan materi pelatihan peserta mengisi angket pemahaman terhadap penulisan PTK, (3) penyelenggaraan seminar berupa penyampaian materi penulisan PTK oleh dosen kepada peserta seminar dalam waktu 6 jam tatap muka, (4) setelah diberikan materi pelatihan peserta mengisi angket pemahan terhadap Penulisan PTK, tujuan pemberian angket adalah untuk mengetahui penigkatan pemahaman guru terhadap PTK, dan (5) tindak lanjut dari pelatihan berupa pendampingan penulisan proposal PTK selama 6 jam. Output dari kegiatan ini adalah meningkatnya pemahaman guru terhadap penulisan PTK dan ketermpilan guru dalam menyusun proposal PTK.

Tahapan ini dimaksudkan untuk melihat ketercapaian target luaran pengabdian, proses pelaksanaan dan hambatan-hambatan yang terjadi dalam pelasanaan kegiatan serta solusi yang dilakukan. Diharapkan dengan adanya 
evaluasi program pengadian kepada masyarakat yang akan dilakukan setelah pelaksaan kegiatan dapat meberikan manfaat baik bagi tim pelaksana, sekolah dan masyarakat.

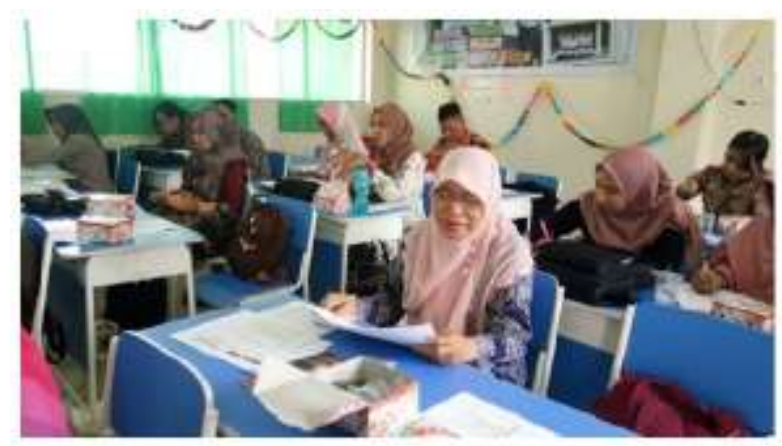

Gambar 1. Peserta mengisi Angket

Dari kegiatan pelatihan ini, terdapat dua target yang dijadikan sasaran ketercapaian kegiatan. Pertama, menambah pemahaman guru terhadap karya tulis ilmiah berupa penelitian tindakan kelas. kedua, dari kegiatan ini target selanjutnya adalah diperoleh rencana judul yang nantinya dapat dikembangkan oleh guru-guru menjadi suatu bentuk penelitian tindakan kelas.

Kedua target sasaran kegiatan dapat terlaksana serta teralisasikan. Berdasarkan tingkat pemahaman guru terhadap materi yang disampaikan terdapat peningkatan pemahaman rata-rata peserta $40 \%$ (Hasil Pretes 40 poin dan post tes 80 poin) dengan target peserta 35 orang, hadir 40 orang (114\%). Berdasarkan jumlah judul yang dihasilkan oleh peserta pelatihan hanya tercapai 40\% (16 judul penelitian).

Akan tetapi, terdapat beberapa hambatan yang terjadi dalam proses pelaksanaanya. Diantara hambatan tersebut, yaitu terjadi keterlambatan di saat pembukaan kegiatan dikarena adanya kesalahan teknis. Pada saat di lokasi kegiatan, ruangan tempat pelaksanaan kegiatan terkunci sehingga sedikit memerlukan waktu untuk mengambil kunci ruangan. Permasalahan ini dapat disiasati oleh tim PKM dengan cara memulai registrasi dahulu sambil menunggu pintu ruangan terbuka. Berkenaan dengan target pemahaman, sebelum pelatihan, peserta masih belum memahami mengenai konsep dan penerapan PTK. Ini dapat dilihat dari hasil tes awal terhadap peserta. Selain itu, berdasarkan pernyataan peserta sebelumnya mereka juga pernah mengikuti kegiatan pelatihan berkenaan 
penelitian. Hanya saja, pelatihan yang dilakukan dirasakan belum tuntas karena apa yang diperoleh dari pelatihan sebelumnya hanya sampai konsep PTK belum ke tahap pengaplikasiannya. Hal ini juga terjadi terhadap kegiatan pelatihan yang dilaksanakan ini.

Hambatan dalam PKM ini adalah dikarenakan keterbatasan waktu, idealnya untuk pelatihan memerlukan waktu hingga enam bulan, akan tetapi dikarenakan keterbatasan waktu serta biaya sehinga kegiatan ini hanya dibatasi selama dua hari saja. Dalam waktu dua hari ini, dimanfaatkan secara optimal dalam pelaksanaanya. Di hari pertama kegiatan difokuskan terhadap pemahaman konsep serta motivasi dalam menghasilkan karya tulis ilmiah. Di hari kedua, kegiatan unjuk kerja berupa peserta setidaknya telah dapat menghasilkan judul serta permasalahan dari penelitian yang direncanakan. Untuk menindak lanjuti dari judul tersebut, maka tim PKM terbuka menerima konsultasi dari para peserta yang berkeinginan untuk melanjutkan penelitiannya.

\section{SIMPULAN}

Kegiatan PKM yang telah dilaksanakan oleh tim dosen Program Studi Pendidikan Bahasa dan Sastra Indonesia IKIP PGRI Pontianak melalui kegiatan Pelatihan penulisan karya tulis ilmiah kepada guru SMP Se-Kota Pontianak dapat disimpulkan bahwa: Pertama, terdapat peningkatan pemahaman guru terhadap karya tulis ilmiah berupa penelitian tindakan kelas tergolong baik sekali. Kedua, diperoleh rencana judul yang dapat dikembangkan oleh guru-guru menjadi bentuk penelitian tindakan kelas tergolong rendah (hanya 16 judul dari 40 peserta pelatihan).

\section{UCAPAN TERIMA KASIH}

Terima kasih tim PKM ucapkan kepada IKIP PGRI Pontianak yang telah mendanai kegiatan ini. Terima kasih kepada pengurus MGMP bahasa Indonesia tingkat SMP Se-Kota Pontianak dan Kepala Sekolah SMPN 2 Pontianak yang telah membantu memfasilitasi peserta dan tempat kegiatan. 


\section{DAFTAR PUSTAKA}

Afandi, M. (2014). Pentingnya penelitian tindakan kelas bagi guru dalam pembelajaran di sekolah dasar. Jurnal ilmiah pendidikan dasar, 1(1), 1-19.

Aqib, Z. (2009). Penelitian tindakan kelas untuk guru. Bandung: Yrama Widya.

Hanifah, N. (2014). Memahami penelitian tindakan kelas: teori dan aplikasinya. Bandung: UPI Press.

Hermawati, W. (2017). Pengaruh motivasi kerja guru dan implementasi program kerja musyawarah guru mata pelajaran (mgmp) terhadap kinerja mengajar guru di MTs negeri model brebes. Syntax literate; jurnal ilmiah Indonesia, 2(9), 170-193.

Kemendikbud. (2016a). Pembinaan dan pengembangan profesi guru buku 4 pedoman kegiatan pengembangan keprofesian berkelanjutan bagi guru pembelajar. Jakarta: Direktorat Jenderal Guru dan Tenaga Kependidikan.

Kemendikbud. (2016b). Pembinaan dan pengembangan profesi guru buku 5 pedoman penilaian kegiatan pengembangan keprofesian berkelanjutan guna mendukung pengembangan profesi guru pembelajar (PPGP). Jakarta: Direktorat Jenderal Guru dan Tenaga Kependidikan.

Langgau, L., \& Mataputun, Y. (2016). Peranan MGMP dalam meningkatkan profesionalisme guru bahasa inggris SMP di kota Jayapura. Mapendik: jurnal manajemen pendidikan universitas cenderawasih, 3(1).

Ma'rifataini, L. (2014). Efektivitas MGMP dalam peningkatan profesionalisme guru mata pelajaran umum di MTs. Edukasi: Vol 12 (1), 70-82.

Suprayitno, A. (2019). Pedoman penyusunan dan penulisan jurnal ilmiah bagi guru. Yogyakarta: Deepublish.

Utomo, S. (2016). Penelitian tindakan kelas untuk angka kredit pengembangan keprofesian berkelanjutan bagi guru. Papua: LPMP

Wiedarti, P., Laksono, K., \& Retnaningsih, P. (2018). Desain induk gerakan literasi sekolah. Jakarta: Direktorat Jenderal Pendidikan Dasar dan Menengah. 